\title{
Bogdan Kasprzyk, Towarzystwo Urzędników Gminy Stołecznego Królewskiego Miasta Krakowa (1872-2017), ss. 456, Kraków 2017, Towarzystwo Urzędników Gminy Stołecznego Królewskiego Miasta Krakowa
}

W pierwszym odruchu można by uznać, że książka Bogdana Kasprzyka to jeszcze jedno okolicznościowe wydawnictwo, popularyzujące co prawda wiedzę, ale skierowane przede wszystkim do zamkniętego grona. Jednakże to wrażenie jest mylne. Recenzowana publikacja oparta bowiem została na bardzo gruntownej i rzetelnie przeprowadzonej kwerendzie archiwalnej. Autor nie ograniczył się do zachowanych akt samego Towarzystwa, ale sięgnął do zasobów archiwów, bibliotek i zbiorów prywatnych dotyczących historii społeczności urzędników krakowskich na przestrzeni ponad stu lat. Książka jest swoistym portretem zbiorowym, w którym badacze nie tylko zagadnień miejskich, ale również historii administracji, antropologii czy genealogii znajdą wiele ważnych informacji.

Założeniem publikacji było spisanie dziejów Towarzystwa Urzędników Gminy Stołecznego Miasta Krakowa od 1872 r., a podstawowym wyzwaniem, przed którym stanął Autor, było zrekonstruowanie jego działalności, co przy niekompletnie i nierównomiernie zachowanej dokumentacji stanowiło wielką trudność. Przy tworzeniu narracji o historii pierwszych trzydziestu i ostatnich dwudziestu pięć lat funkcjonowania stowarzyszenia Autor miał do dyspozycji wiele źródeł i z konieczności musiał dokonywać ich selekcji. Natomiast dzieje lat 1939-1960 okrywa mrok. Podstawą opracowania są źródła archiwalne, szczególnie dokumenty urzędowe, wspomnienia stanowią uzupełnienie relacji, jej dopełnienie.

Wśród tak niewielu zachowanych akt wytworzonych przez samo Towarzystwo najważniejsza jest „Księga protokołów od 1872 r. do 1939” (od pierwszego protokołu zebrania założycielskiego) zawierająca 98 protokołów wraz z załącznikami (sprawozdania, statuty, budżety). Jest to nieocenione źródło wiedzy. Sama księga po 1939 r. przechowywana była przez członków Towarzystwa, a później w magistrackim Archiwum. Tam po reak- 
tywowaniu Towarzystwa Maria Guberniak, członek władz Towarzystwa, ją odnalazła i zabezpieczyła.

Omawiane wydawnictwo zostało wydane dla upamiętnienia jubileuszu 145-lecia założenia i 25-lecia odrodzenia Towarzystwa. Treść została zaprezentowana w układzie tematycznym, a następnie chronologicznie. Autor w sposób logiczny i uporządkowany poprowadził narrację przez etapy dziejowe Towarzystwa: powstanie, okrzepnięcie (1872-1896), rozwój i hossę (1896-1939), upadek (1939-1992), odrodzenie, aż do stabilizacji (od 1992). Następnie przedstawił atrybuty władzy, takie jak: nazwa (jej przekształcenia), statuty, pieczęcie oraz siedziba.

Niezwykle ważną częścią książki jest rozdział poświęcony ludziom, którzy działali w Towarzystwie. Szeroka analiza ilościowa i jakościowa jego członków to bardzo dobry przyczynek do powstania w przyszłości portretu zbiorowego tej grupy społecznej. Już dziś na podstawie zebranych przez Autora informacji można naszkicować jej ewoluujący obraz: na początku mocno konserwatywna i zmaskulinizowana, a obecnie zdecydowanie sfeminizowana, co odzwierciedla zmiany społeczne w stanie zatrudnienia w samorządzie.

Zaprezentowany został również pełen przegląd członków: honorowych, założycieli, zwyczajnych i uczestników w latach 1872-1940, jak również członków Towarzystwa po pierwszej reaktywacji w latach 1947-1960 oraz członków zwyczajnych i uczestników w latach 1992-2017.

Następnie Autor skoncentrował się na omówieniu kolejnych władz Towarzystwa oraz jego agend. Nie wolno bowiem zapomnieć, że w okresie rozkwitu działalności (dwudziestolecie międzywojenne) Towarzystwo prowadziło konsum ${ }^{1}$ i sklep (1915-1918, 1940-1941), czytelnię i bibliotekę (1923-1940), dom (od 1929), chór (1929-1940), zakład fryzjerski (19321940) oraz sekcję kajakarską z przystanią (1935-1940).

Nie można odmówić słuszności Autorowi, gdy krótko charakteryzuje linię czasu historii Towarzystwa: „Oto powstanie, narodziny (rok 1872) oraz czas okrzepnięcia, dojrzewania do swego pełnego kształtu (do roku 1896). Następnie systematyczny rozwój, wzrost, aż do osiągnięcia największej siły i czasu prosperity (lata 1896-1939). I nagle upadek, upadek trwały, z bezskuteczną próbą podźwignięcia się (lata 1940-1992). Aż nadszedł etap od-

\footnotetext{
${ }^{1}$ Konsum - sklep zakładowy, nie był ogólnie dostępny dla wszystkich klientów, tylko np. dla pracowników i członków ich rodzin.
} 
rodzenia, odbudowy i ustabilizowania z dobrą perspektywą na przyszłość (od roku 1992)".

Trzeba również zwrócić szczególną uwagę na to, że II wojna światowa zniweczyła szanse na pomyślny rozwój Towarzystwa, a powojenna zmiana ustrojowa wykluczyła funkcjonowanie stowarzyszeń zawodowych w przedwojennej formie. Autorowi niestety nie udało się zrekonstruować pierwszych piętnastu lat powojennych. Z powodu braku źródeł ten czas w dziejach Towarzystwa to niewypełniona luka. Tym bardziej za sukces należy uznać nakreślenie szkicu dziejów tego okresu na podstawie szczątkowo zachowanych źródeł. Wynika z niego, że Towarzystwo po wojnie było „uśmiercane” przez władze dwukrotnie. Czas zadośćuczynienia przyszedł ze zmianą ustrojową w 1989 r. i odnowieniem się samorządu terytorialnego w $1990 \mathrm{r}$.

Wydawnictwo zostało dopełnione Kalendarium historii oraz galerią, ponadto czytelnik znajdzie pełne teksty kolejnych statutów Towarzystwa. Tabele, schematy, infografiki - jasno i przejrzyście prezentują najważniejsze informacje.

Z obowiązku recenzenckiego chciałabym zwrócić uwagę na kilka spraw. Na s. 18 Autor wspomina, że tymczasowy statut przetrwał do 1891 r., w rzeczywistości obowiązywał on do 1901 r., kiedy to uchwałą sejmową po wielu dyskusjach i proceduralnych perturbacjach wprowadzono nowy statut, który wszedł w życie w 1902 r.

$\mathrm{Na}$ tej samej stronie Autor zastosował pewien skrót myślowy, w wyniku którego powstało terminologiczne nieporozumienie: „ukształtował się Magistrat jako zespół miejskich urzędników samorządowych oraz służb towarzyszących, zwanych wtedy sługami miejskimi”. Służby towarzyszące to nie sługi miejskie, tylko m.in. agendy Magistratu, obejmujące zarówno urzędników, jak i sługi, którzy podlegali wydziałom.

Na s. 33 Autor traktuje jako wyjątek członkostwo Wincentego Eminowicza (w 1872 r.), który był wówczas komendantem straży pożarnej i jednocześnie „etatem bezpośrednio magistrackim”. Tymczasem do 1950 r. sprawy pracownicze wszystkich urzędników i sług zarówno magistrackich, urzędów pomocniczych oraz służb (jak Straż ogniowa) i innych jednostek (jak np. szkoły) były prowadzone w Magistracie, ale to nie znaczy, że to były etaty magistrackie. W skład Magistratu wchodziły tylko: prezydium, wydziały, kasa miejska (ale już nie Wydział Obrachunkowy), budowniczy miejski, fizyk miejski, komisarze obwodowi. 
Korektę również należałoby wprowadzić do nazw zespołów przechowywanych w Archiwum Narodowym w Krakowie. Zespoły, które w bibliografii zostały wykazane jako odrębne, czyli: Zespół Magistrat Miasta Krakowa (sygn. Mag II 326, Mag II 1355, Mag II 1356, Mag II 1357, Mag II 1358, Mag II 1715, Mag II 1716) oraz Zespół Starostwo Miejskie Krakowskie (sygn. SMKr 421, SMKr 425, SMKr 428, SMKr 430) w rzeczywistości przynależą do jednego zespołu archiwalnego Akt miasta Krakowa z lat (1257-1950) i są to kolejne serie dokumentacji.

Wymienione drobne uwagi nie przesłaniają jednak faktu, że ukazało się wydawnictwo będące kompendium wiedzy o systemie wsparcia dla pracowników gminy krakowskiej przez dziesięciolecia. To historia, analiza administracyjno-prawna, zbiór dokumentów źródłowych oraz, co nie mniej ważne, zestawienie blisko 1000 nazwisk członków Towarzystwa z przebiegiem ich karier zawodowych oraz wzmiankami o działalności w Towarzystwie. Zarówno dla historyka administracji, jak i dla genealoga jest to pozycja obowiązkowa.

Warto podkreślić, że również pod względem edytorskim wydawnictwo zostało niezwykle starannie przygotowane. Do rąk czytelników trafiło bowiem wydanie albumowe, z piękną grafiką i typografią, w twardej oprawie. Szata graficzna nawiązuje do monumentalnego pocztu ${ }^{2}$ wydawanego przez Urząd Miasta Krakowa, co jest w pełni uzasadnione, bo łączy je nie tylko osoba Autora, ale również tematyka funkcjonowania gminy miejskiej Kraków.

Myślę, że nie będzie z mojej strony przesadą, gdy powiem, że publikacja ta stanowi bardzo ważne opracowanie dla wszystkich, nie tylko zainteresowanych poszczególnymi osobami związanymi z Towarzystwem czy samą historią organizacji. To od teraz podstawowa pozycja dla naukowców, którzy będą przeprowadzać jakiekolwiek analizy stowarzyszeń, form samopomocy oraz zaradności i przedsiębiorczości różnych grup zawodowych.

Monika Andrasz-Mrożek

2 Poczet soltysów, wójtów, burmistrzów i prezydentów miasta Krakowa (1228-2010), red. Bogdan Kasprzyk, Kraków 2010; Bogdan Kasprzyk, Poczet soltysów, wójtów i burmistrzów miast, jurydyk, wsi i gmin przyłączonych do Krakowa do 1915 roku, Kraków 2013; idem, Poczet soltysów i wójtów wsi, gmin i gromad przyłaczonych do Krakowa po 1915 roku, Kraków 2015; idem, Poczet zwierzchników dzielnic miasta Krakowa (1396-2018), Kraków 2018. 